\title{
Dietary Brazilian red pepper essential oil on pork meat quality and lipid oxidation
}

\author{
Franz Dias Gois ${ }^{1 *}$ Maicon Sbardella ${ }^{2}$ Cristiane Bovi de Lima $^{3}$ Dannielle Leonardi Migotto \\ Pedro Leon Gomes Cairo ${ }^{1}$ Cesar Augusto Pospissil Garbossa ${ }^{4}$ \\ Aline Mondini Calil Racanicci ${ }^{3}$ Leandro Batista Costa $^{5}$
}

\author{
${ }^{1}$ Departamento de Ciências Agrárias e Ambientais, Universidade Estadual de Santa Cruz (UESC), 45662-900, Ilhéus, BA, Brasil. E-mail: \\ fdgois16@gmail.com. *Corresponding author. \\ ${ }^{2}$ Departamento de Zootecnia, Universidade de São Paulo (USP), Piracicaba, SP, Brasil. \\ ${ }^{3}$ Faculdade de Agronomia e Medicina Veterinária, Universidade de Brasília (UnB), Brasília, DF, Brasil. \\ ${ }^{4}$ Departamento de Zootecnia, Universidade Federal de Lavras (UFLA), Lavras, MG, Brasil. \\ ${ }^{5}$ Escola de Ciências da Vida, Pontifícia Universidade Católica do Paraná (PUCPR), Curitiba, PR, Brasil.
}

\begin{abstract}
The purpose of this study was to evaluate the effects of feeding pigs with diets containing increasing levels of Brazilian red pepper essential oil (Schinus terebinthifolius Raddi) on the physical attributes, fatty acid profile and oxidative stability of precooked meat. Seventy-two weanling pigs $(5.7 \pm 0.8 \mathrm{~kg})$ were allotted in a completely randomized block design experiment with four treatments, six replicates per treatment, and three animals per experimental unit (pen). Animals were fed with a basal diet supplemented with 0, 500, 1,000, or 1,500mg $\mathrm{kg}^{-1}$ Brazilian red pepper essential oil during the 35-d experimental period. At the end of the experiment, one animal per experimental unit $(16.4 \pm 2.2 \mathrm{~kg})$ was slaughtered to sample Longissimus dorsi muscle for analysis. Dietary supplementation of Brazilian red pepper had no effect $(P>0.05)$ on pork meat color, $\mathrm{pH}$, cooking loss and shear force. Inclusion of essential oil in the diet provided a linear increase (P<0.05) of the saturated fatty acids content of L. dorsi, especially myristic (C14:0) and stearic (C18:0) fatty acids. Utilization of essential oil in pig diets reduced significantly the production of secondary lipid oxidation compounds measured as TBARS in raw pork meat $(P<0.001)$ and immediately after cooking $(P<0.001)$. However, during 8-d storage assay, the addition of essential oil in the diet did not protect pork meat lipids from oxidation. Therefore, Brazilian red pepper added to pig diets increased the saturated fatty acids content and reduced lipid oxidation in fresh meat and short-term heat treatment without affecting pork meat physical attributes.

Key words: antioxidative effect, fatty acid composition, muscle, natural feed additive.
\end{abstract}

Óleo essencial de aroeira na qualidade da carne suína e oxidação lipídica

RESUMO: O objetivo deste estudo foi avaliar os efeitos da adição do óleo essencial de aroeira (Schinus terebinthifolius Raddi) na dieta de suínos sobre as características físicas, composição química e oxidação lipídica da carne. Setenta e dois leitões recém-desmamados (5,7¥0,8kg) foram utilizados em um experimento em blocos completos casualizados com quatro tratamentos, seis repetições por tratamento e três animais por unidade experimental (baia). Os animais foram alimentados com uma dieta basal suplementada com 0, 500, 1,000 ou 1,500mg $\mathrm{kg}^{-1}$ de óleo essencial de aroeira durante 35 dias. Ao final do experimento, um animal por unidade experimental (16,4 $\pm 2,2 \mathrm{~kg})$ foi abatido para coleta do músculo Longissimus dorsi para fim de análises. Não houve efeito $(P>0,05)$ do óleo essencial de aroeira sobre cor, pH, perda de peso por cozimento e força de cisalhamento. A inclusão de níveis crescentes do óleo essencial de aroeira na dieta aumentou linearmente (P<0,05) $o$ conteúdo de ácidos graxos saturados do músculo dos suínos, principalmente, as concentrações de mirístico (C14:0) e esteárico (C18:0). Para as análises de TBARS, a inclusão de óleo essencial de aroeira reduziu, significativamente, a produção de compostos secundários da oxidação lipídica nas amostras de carne crua $(P<0,001)$ e imediatamente após o cozimento $(P<0,001)$. Entretanto, durante oito dias de armazenamento refrigerado, a adição do óleo essencial de aroeira não protegeu eficientemente $(P>0,05)$ os lipídios da oxidação. Portanto, o óleo essencial de aroeira, adicionado às dietas para suínos, aumentou o conteúdo de ácidos graxos saturados e reduziu a oxidação lipídica na carne fresca e logo após cozimento, sem ocorrer efeitos sobre os parâmetros físicos da carne.

Palavras-chave: efeito antioxidante, composição de ácidos graxos, músculo, aditivo natural.

\section{INTRODUCTION}

The pork meat is highly susceptible to oxidative alterations due to the high content of polyunsaturated fatty acids (YI et al., 2013). Lipid oxidation process is one of the main factors related to meat deterioration, affecting nutritional and sensory traits due to the formation of free radicals and an unpleasant smell (SIMITZIS et al., 2010). In addition to negatively effects on the acceptance of the product by consumers, the lipid oxidation process may have side effects on health, e.g., chronic diseases like cancer and cardiovascular diseases (MORONEY et al., 2012; YI et al., 2013). 
Aiming to prolong the shelf life of meat products, synthetic antioxidants have been added to animal diets or during the meat processing to inhibit the advance of the oxidative process (SIMITZIS et al., 2010). However, concerns about the food safety have fostered the demand for products free of synthetic antioxidants, increasing the interest for natural products (ROSSI et al., 2013).

Utilization of natural compounds as natural antioxidant and antimicrobial as a part of the alternative feeding strategies for animals has increased significantly (AO et al., 2011; ROSSI et al., 2013). Among the benefits of the dietary utilization of natural essential oils, the following stand out: antioxidant properties, increase in digestive secretions, improvement of digestibility and absorption of nutrients, stimulation of the immune system and antibacterial, coccidiostatic, antihelmintic, antiviral, and anti-inflammatory activities (HASHEMI \& DAVOODI, 2011).

Brazilian red pepper (Schinus terebinthifolius Raddi; Anacardiaceae) essential oil has a large diversity of secondary metabolites with functional properties, such as terpenoids and phenolic compounds with therapeutic applications as antibacterial (COLE et al., 2014), antioxidant (BENDAOUD et al., 2010; JERIBI et al., 2014) and gut health promoter (SILVA et al., 2010; GOIS et al., 2016). However, to this day, there is little information in the literature on its use as a feed additive in pig diets to improve meat characteristics.

The purpose of this study was to evaluate the effects of dietary Brazilian red pepper essential oil on the physical attributes, fatty acid profile and lipid oxidation of precooked pork meat.

\section{MATERIALS AND METHODS}

Seventy-two weanling castrated male pigs (female DanBred - DB90 x male PICAGPIC 337) $(5.7 \pm 0.8 \mathrm{~kg} \mathrm{BW})$ were distributed in a randomized complete block design experiment with four treatments, six replications per treatment, and three animals per experimental unit (pen). Pigs had ad libitum access to water and feed throughout the 35-d feeding experiment.

Treatments were 0 (control treatment); $500,1,000$ or $1,500 \mathrm{mg} \mathrm{kg}^{-1}$ of Brazilian red pepper essential oil (AgroRosa Ltda, São Mateus, ES, Brazil). Diets were formulated according to the nutritional requirements for pigs (ROSTAGNO et al., 2011) with a two-step nutritional program: pre-starter $\left(1^{\text {st }}\right.$ to $14^{\text {th }}$ day of the experiment $)$ and starter $\left(14^{\text {th }}\right.$ to $35^{\text {th }}$ day of the experiment). Diets were formulated based on corn, soybean meal, dairy products, minerals and vitamins to contain 14.6 and $14.2 \mathrm{MJ}$ $\mathrm{kg}^{-1}$ metabolizable energy, 20.2 and $20.6 \%$ crude protein, and 1.5 and $1.4 \%$ digestible lysine for prestarter and starter, respectively.

Brazilian red pepper essential oil was produced by extraction using steam distillation technique and only mature fruits. Composition of essential oil was determined using a gas chromatograph $(6890 \mathrm{~N}$, Agilent Technologies, Santa Clara, USA) with a mass detector (5973, Agilent Technologies), equipped with a DB-5MS silica column $(60 \mathrm{~m} \times 0.32 \mathrm{~mm} \times 1.0 \mu \mathrm{m})$. Identification was confirmed using standard compounds that were available in the chosen library (Givaudan Ltda., São Paulo, SP, Brazil). The essential oil from pepper tree fruit contained $41.0 \% \delta$-3-carene, $14.4 \%$ $\alpha$-phellandrene, $12.4 \%$ limonene, $10.4 \% \alpha$-pinene, and $21,9 \%$ of other compounds. The product used in the experimental feeding trial contained $15 \%$ of essential oil and was microencapsulated to reduce the marked taste and provide stability of the active compounds (Givaudan Ltda., São Paulo, SP, Brazil).

After the 35-d experimental period, one animal from each experimental unit $(16.4 \pm 2.2 \mathrm{~kg}$ $\mathrm{BW}$ ) with body weight close to the average weight of the pen was slaughtered $(n=6)$ under experimental conditions to collect Longissimus dorsi muscle for physical attributes analysis (objective color, $\mathrm{pH}$, cooking loss and shear force), fatty acid profile and stability of lipids in precooked meat balls during chilled storage.

Physical analyses started in L. dorsi muscle after $24 \mathrm{~h}$ of chilled $\left(4^{\circ} \mathrm{C}\right)$ storage. Color measurements (CIELAB system based on $\mathrm{L}^{*}=$ lightness; $\mathrm{a}^{*}=$ red component; $b^{*}=$ yellow component) were performed in the meat samples after exposition to air but not to light for $20 \mathrm{~min}\left(10^{\circ} \mathrm{C}\right)$ and assessments were made randomly in triplicate on the ventral part of the meat patty using a Konika Minolta colorimeter (Chroma Meter CR-400, Konika Minolta Sensing Inc, Japan). For $\mathrm{pH}$, three random evaluations were performed in each sample using a portable $\mathrm{pH}$ meter with penetration electrode (Testo 205, Testo Limited, Hampshire, UK). To measure the cooking loss (CL), pork meat cubes were cut $(2.5 \mathrm{~cm} \times 2.5 \mathrm{~cm} \times 2.5 \mathrm{~cm})$ in duplicate, weighed and cooked in an industrial oven pre-heated to $170^{\circ} \mathrm{C}$ until internal temperature reached $70^{\circ} \mathrm{C}$, controlled with a thermometer type $\mathrm{K}$ (Testo 922, Limited, Hampshire, UK) connected to a probe inserted in the center of the cubes. After cooking, meat cubes were cooled down at room temperature 
and weighed again to calculate the cooking loss by difference. After weighing, meat cubes were stored for $24 \mathrm{~h}\left(4^{\circ} \mathrm{C}\right)$ to perform shear force $(\mathrm{SF})$ evaluations. Subsamples were obtained after sectioning, from each prepared cube, by using a cylindrical $1.27-\mathrm{cm}$ diameter sampler, removed in the parallel direction of the muscle fibers and sheared perpendicularly to the muscle fibers to obtain maximum shear force using a Warner-Bratzler (Model 235 6X, GR Manufacturing Co., Manhattan, KS) device with a V-type blade $(1.016 \mathrm{~cm}$ thickness and constant speed of $200 \mathrm{~mm}$ $\left.\mathrm{min}^{-1}\right)$. Results were expressed in Newton (N).

The remaining samples of $L$. dorsi muscle were vacuum-packed and stored frozen $\left(-20^{\circ} \mathrm{C}\right)$ during 100 days until the beginning of the chemical analyses. Frozen $L$. dorsi muscles samples were ground and mixed with $0.5 \%$ of salt to prepare the meat balls as described by RACANICCI et al. (2011). Lipid oxidation was evaluated by the quantification of the secondary lipid oxidation products using TBARS (thiobarbituric acidreactive substances) method (MADSEN et al., $1998)$ performed in both raw and precooked $\left(100^{\circ} \mathrm{C}\right.$ for $10 \mathrm{~min}$. in boiling water) meatballs and also during chilled storage on days $0,3,6$, and 8 . For each period, two meatballs from each treatment were analyzed in duplicate and results were expressed in milligrams of malondialdehyde per kilogram of meat (mg MDA kg-1).

Fat extractions and fatty acid composition were performed in four precooked meatballs to determine the fatty acid profile as described by BLIGH \& DYER (1959) modified in the stirring step (Ultra Turrax, IKA, model T25 digital). After methylation (HARTMAN \& LAGO, 1973), the fatty acid profile was determined using gas chromatography of methyl esters of fatty acids, according to official method 1-62 AOCS (1998).

The MIXED procedure of SAS (SAS Institute Inc., Cary, North Carolina, USA) was utilized for the ANOVA, considering a completely randomized experimental design according to the following model: $Y(i j)=\mu+1(\mathrm{i})+\varepsilon(\mathrm{ij})$, where $\mathrm{Y}(\mathrm{ij})$ is the dependent response; $\mu$ is the overall mean; 1(i) is the fixed effect of the levels of Brazilian red pepper essential oil in the $\operatorname{diet}(\mathrm{i}=1, \ldots 4)$; and $\varepsilon(\mathrm{ij})$ is the residual error.

The data of the meat physical attributes were analyzed using one-way ANOVA, where diet was the main factor and the Longissimus dorsi muscle of each slaughtered animal (one pig per pen) was considered an experimental unit, totaling six replicates per treatment. One-way ANOVA was also used for fatty acid profile analyses, where precooked meat balls (made from a pool of $L$. dorsi muscle of the six castrated male pigs slaughtered per treatment) were considered experimental units totaling four replicates for the fatty acid profile per treatment. TBARS values from the storage assay were analyzed using a two-way ANOVA, where the random repeated effect of storage time was added to the general model and precooked meat balls were considered to be experimental unit, totaling four replicates for TBARS-values per treatment per storage time.

ANOVA $(P \leq 0.05)$ is reported in the tables. Tukey's test was used to compare the TBARS and fatty acid profile means of the dietary treatments. Orthogonal contrasts and polynomial regression analyses were performed to determine the dose-response to dietary Brazilian red pepper essential oil levels.

\section{RESULTS}

No differences were observed $(\mathrm{P}>0.05)$ between the dietary treatments for color $\left(\mathrm{L}^{*}, \mathrm{a}^{*}\right.$, and $\left.b^{*}\right), p H$, cooking loss (CL) and shear force (SF) parameters of the pork meat (Table 1).

The addition of Brazilian red pepper showed a linear increase $(\mathrm{P}<0.01)$ in the content of saturated fatty acids in pre-cooked pork meatballs. This effect was observed mainly on the elevation of myristic $(\mathrm{C} 14: 0)(\mathrm{P}<0.05)$ and stearic $(\mathrm{C} 18: 0)$ $(\mathrm{P}<0.03)$ fatty acids of the meat fat fraction over the reduction $(\mathrm{P}<0.02)$ of the palmitoleic acid values (C16:1) (Table 1).

The dietary utilization of Brazilian red pepper essential oil to pigs provided a certain protection, as seen on the reduction on the TBARS values in raw meatballs $(\mathrm{P}<0.001)$ and immediately after cooking $(\mathrm{P}<0.001)$. However, the addition of red pepper essential oil did not protect the lipids from oxidation during eight days of chilled storage (Table 2).

\section{DISCUSSION}

Color is an important quality attribute for the pork industry due to the influence on the choice and acceptance of consumers at the time of purchase (DRANSFIELD et al., 2005; VERBEKE et al., 2010). The addition of Brazilian red pepper essential oil to the pigs diets did not influenced the color of the Longissimus muscle, as reported in earlier studies using plant-based dietary additives (LAHUCKY et al., 2010; ROSSI et al., 2013).

In general, the $b^{*}$ component value quantifies carotenoid pigments that are deposited in 
Table 1 - Color $\left(\mathrm{L}^{*}, \mathrm{a}^{*}\right.$, and $\left.\mathrm{b}^{*}\right), \mathrm{pH}$, cooking loss (CL), shear force (SF), and fatty acid profile (\% of total fatty acids) of the Longissimus muscle of pigs fed diets containing increasing concentrations of Brazilian red pepper essential oil for 35-d.

\begin{tabular}{|c|c|c|c|c|c|c|c|}
\hline \multirow{2}{*}{ Item } & \multicolumn{4}{|c|}{ 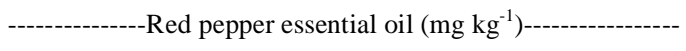 } & \multirow{2}{*}{ SEM $^{\mathrm{i}}$} & \multirow{2}{*}{$\mathrm{CV}^{\mathrm{ii}}$} & \multirow{2}{*}{ P-value } \\
\hline & 0 & 500 & 1,000 & 1,500 & & & \\
\hline $\mathrm{L}^{*}$ & 55.73 & 54.67 & 58.12 & 56.93 & 1.17 & 4.91 & 0.24 \\
\hline$a^{*}$ & 5.86 & 4.17 & 4.93 & 5.13 & 0.54 & 25.38 & 0.23 \\
\hline $\mathrm{b}^{*}$ & 7.92 & 6.21 & 7.12 & 6.72 & 0.59 & 19.60 & 0.26 \\
\hline $\mathrm{pH}$ & 5.43 & 5.49 & 5.50 & 5.42 & 0.04 & 17.35 & 0.38 \\
\hline Cooking loss, $\%$ & 24.00 & 21.69 & 23.10 & 23.37 & 0.94 & 9.25 & 0.40 \\
\hline Shear force, $\mathrm{N}$ & 22.35 & 20.84 & 20.59 & 24.72 & 1.60 & 16.82 & 0.29 \\
\hline $\mathrm{C} 14: 0^{\mathrm{a}}$ & $1.10 \mathrm{a}$ & $1.17 \mathrm{ab}$ & $1.14 \mathrm{ab}$ & $1.19 \mathrm{~b}$ & 0.02 & 3.92 & 0.05 \\
\hline C14:1 & 1.72 & 1.71 & 1.68 & 1.81 & 0.09 & 8.27 & 0.75 \\
\hline $\mathrm{C} 16: 0$ & 24.24 & 24.51 & 23.90 & 24.58 & 0.25 & 1.85 & 0.43 \\
\hline $\mathrm{C} 16: 1^{\mathrm{b}}$ & $1.77 \mathrm{a}$ & $1.54 \mathrm{~b}$ & $1.57 \mathrm{~b}$ & $1.63 \mathrm{ab}$ & 0.03 & 6.40 & 0.02 \\
\hline C17:0 & 1.24 & 1.14 & 1.19 & 1.31 & 0.03 & 6.95 & 0.08 \\
\hline $\mathrm{C} 18: 0^{\mathrm{c}}$ & $11.30 \mathrm{a}$ & $12.28 b$ & $12.01 \mathrm{ab}$ & $12.13 \mathrm{ab}$ & 0.15 & 3.90 & 0.03 \\
\hline C18:1 & 34.56 & 33.96 & 35.12 & 33.51 & 0.69 & 3.59 & 0.47 \\
\hline C18:2 & 20.33 & 20.04 & 19.58 & 19.84 & 0.55 & 4.44 & 0.81 \\
\hline C23:0 & 3.75 & 3.65 & 3.71 & 3.98 & 0.43 & 17.63 & 0.95 \\
\hline $\mathrm{SFA}^{\mathrm{d}}$ & $41.62 \mathrm{a}$ & $42.77 \mathrm{bc}$ & $42.04 \mathrm{ac}$ & $43.19 \mathrm{bd}$ & 0.15 & 1.64 & 0.01 \\
\hline UFA & 38.06 & 37.21 & 38.38 & 36.96 & 0.63 & 3.01 & 0.43 \\
\hline PUFA & 20.33 & 20.04 & 19.58 & 19.84 & 0.55 & 4.44 & 0.81 \\
\hline PUFA/SFA & 0.48 & 0.47 & 0.46 & 0.46 & 0.01 & 4.96 & 0.65 \\
\hline
\end{tabular}

${ }^{\mathrm{i}}$ Standard error of the mean

ii Coefficient of variation.

${ }^{a}$ Linear effect of dietary Brazilian red pepper on the $\mathrm{C} 14: 0$ values of precooked meatballs $(\mathrm{y}=0.000005 \mathrm{x}+1.114 ; \mathrm{R} 2=0.63 ; \mathrm{P}=0.025)$.

${ }^{\mathrm{b}}$ Quadratic effect of dietary Brazilian red pepper on the $\mathrm{C} 16: 1$ values of pre-cooked meatballs $\left(\mathrm{y}=-0.007 \mathrm{x}^{2}-0.0005 \mathrm{x}+1.7555 ; \mathrm{R}^{2}=0.87\right.$; $\mathrm{P}=0.008)$

${ }^{\mathrm{c}}$ Quadratic effect of dietary Brazilian red pepper on the C18:0 values of pre-cooked meatballs $\left(\mathrm{y}=0.0000000007 \mathrm{x}^{2}+0.0017 \mathrm{x}+11.382\right.$; $\left.\mathrm{R}^{2}=0.76 ; \mathrm{P}=0.048\right)$.

${ }^{\mathrm{d}}$ Linear effect of dietary Brazilian red pepper on the saturated fatty acid profile of pre-cooked meatballs $\left(\mathrm{y}=0.0008 \mathrm{x}+41.808 ; \mathrm{R}^{2}=0.53\right.$; $\mathrm{P}=0.045)$.

the meat fat (BRESSAN et al., 2004) and alterations in the $b^{*}$ value may be indicative of changes in the fatty acid composition of the intramuscular fat (JOO et al., 2002). However, although an increase in the saturated fatty acid content was observed in the present study, no effects were detected on $b^{*}$ value. This can be explained by the fact that young pigs, as used in this study, appears to have the major lipid deposition in the subcutaneous layer and start later intramuscular fat deposition (CISNEROS et al., 1996) that could be detected in color evaluation.

The $\mathrm{pH}$ values observed in this study are within the expected range for pork meat (RYU \& KIM, 2005) and were not affected by dietary treatments, as cooking loss (CL). Similar results were reported in the literature when pigs were fed with plant extract from Lippia spp. (ROSSI et al., 2013), Melissa officinalis or Origanum vulgaris (LAHUCKY et al., 2010).
The inclusion of dietary Brazilian red pepper essential oil significantly reduced the lipid oxidation in raw and immediately after cooking meatballs. This appears to be associated with the linear increase on the content of saturated fatty acids observed as the levels of the dietary essential oil increased, as previously described in the literature (JOO et al., 2002; FUENTES et al., 2014).

During chilled storage, TBARS values of precooked pork meatballs increased significantly, as expected; in addition, the supplementation of Brazilian red pepper essential oil was not effective to protect lipids from oxidation after by day 3 of chilled storage. The antioxidant potential of Brazilian red pepper is linked to the protective effect attributed to the phenolic compounds and terpenoids, which act as natural antioxidants through their ability to eliminate radicals, inhibiting the development and propagation of oxidation reactions, chelating transition metals, 
Table 2 - Secondary products of lipid oxidation measured as TBARS (mg MDA kg-1 meat) during chilled storage $\left(4^{\circ} \mathrm{C}\right)$ in raw and precooked meat balls from pigs fed with diets containing increasing concentrations of Brazilian red pepper essential oil.

\begin{tabular}{|c|c|c|c|c|c|c|c|c|c|}
\hline \multirow{2}{*}{ Item } & \multicolumn{4}{|c|}{---------Red pepper essential oil $\left(\mathrm{mg} \mathrm{kg}^{-1}\right)$------- } & \multirow{2}{*}{ Average } & \multirow{2}{*}{ SEM $^{\mathrm{i}}$} & \multicolumn{3}{|c|}{ - } \\
\hline & 0 & 500 & 1,000 & 1,500 & & & Treat. & Day & Treat.xDay \\
\hline $\mathrm{Raw}^{\mathrm{a}}$ & $1.38 \mathrm{a}$ & $0.74 \mathrm{~b}$ & $0.87 b c$ & $1.02 \mathrm{c}$ & 1.00 & 0.04 & $<0.01$ & - & - \\
\hline \multicolumn{10}{|c|}{$\begin{array}{l}\text { Precooked (days of } \\
\text { storage) }\end{array}$} \\
\hline $0^{\mathrm{b}}$ & $1.97 \mathrm{a}$ & $1.13 b$ & $0.92 b$ & $0.95 b$ & 1.24 & 0.26 & 0.01 & $<0.01$ & 0.14 \\
\hline 3 & 21.37 & 23.12 & 21.43 & 21.45 & 21.84 & & & & \\
\hline $6^{\mathrm{c}}$ & $28.19 a$ & $30.46 \mathrm{~b}$ & $29.23 \mathrm{ab}$ & $29.25 \mathrm{ab}$ & 29.28 & & & & \\
\hline 8 & 34.10 & 35.65 & 33.26 & 34.50 & 34.38 & & & & \\
\hline Average & 21.41 & 22.59 & 21.21 & 21.54 & & & & & \\
\hline
\end{tabular}

${ }^{\text {i }}$ Standard error of the mean.

${ }^{a}$ Quadratic effect of dietary Brazilian red pepper on the TBARS values of pre-cooked meat balls $\left(y=0.000000007 \mathrm{x}^{2}-0.0014 \mathrm{x}+1.3425 ; \mathrm{R}^{2}=0.88\right.$; $\mathrm{P}<0.001)$.

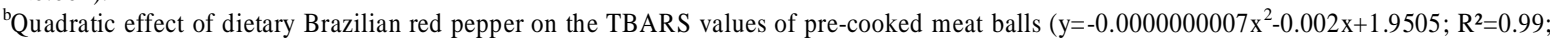
$\mathrm{P}<0.001$ ).

${ }^{c}$ Quadratic effect of dietary Brazilian red pepper on the TBARS values of pre-cooked meat balls $\left(y=-0.0006 x^{2}-0.0038 x+28.428 ; R^{2}=0.56\right.$; $\mathrm{P}=0.0154)$.

especially copper and iron, and converting them into stable products (BENDAOUD et al., 2010; SIMITZIS et al., 2010; JERIBI et al., 2014).

Considering the lack of studies on the effects of Brazilian red pepper essential oil on the oxidative stability of pork meat, comparison of results reported in this research is a difficult task. However, compared with other plant-based antioxidants studies, similar results were reported by ROSSI et al. (2013) and AO et al. (2011) evaluating dietary addition of Lippia spp. (Verbenaceae) and Saururus chinensis that observed antioxidant effect in raw meat samples and subsequent lack of protection during storage probably due to the accumulation of lipid oxidation products. Besides that, in addition to the composition of the essential oil and the dietary level, the short half-life of the active compounds from the essential oils can determine the antioxidant response, considering that thermal processing and storage time could accelerate the degradation of the antioxidant compounds accumulated in the muscle membranes, limiting the antioxidant action to the initial stages of oxidation.

Although dietary supplementation is a simple solution and a convenient strategy to incorporate natural antioxidant compounds into the muscle phospholipid membranes and to enhance in vivo antioxidant system leading to an effective and uniform antioxidant protection in tissues (VISSERS et al., 2004; RIETJENS et al., 2007), little is known about the metabolic pathways of antioxidant compounds and their potential for muscle accumulation.

\section{CONCLUSION}

Dietary supplementation of Brazilian red pepper essential oil increased the saturated fatty acids content of the $L$. dorsi muscle without affecting physical characteristics of the meat. The oxidation of pork meat lipids was reduced by the inclusion of red pepper essential oil, although the results were limited to raw meat and immediately after cook. In conclusion, Brazilian red pepper essential oil seems an interesting natural additive to pigs; thus, more studies are needed to better elucidate the absorption pathways, mechanisms of action and possible effects of the active components on pigs metabolism.

\section{BIOTHICS AND BIOSSECURITY COMMITTEE APPROVAL}

All procedures involving animals were approved by the Ethics Committee on Animal Use of Universidade Estadual de Santa Cruz (CEUA/UESC), protocol 024/2011.

\section{REFERENCES}

AO, X. et al. Effects of Saururus chinensis extract supplementation on growth performance, meat quality and slurry noxious gas emission in finishing pigs. Livestock Science, v.138, p.187-192, 2011. Available from: <http://www.sciencedirect.com/science/ article/pii/S1871141311000114>. Accessed: Dec. 27, 2015. doi: 10.1016/j.livsci.2010.12.029. 
AOCS. Official methods and recommended practices of the American Oil Chemists' Society. 3.ed. Champaign, 1998. V.1-2.

BENDAOUD, H. et al. Chemical composition and anticancer and antioxidant activities of Schinus molle L. and Schinus terebinthifolius Raddi berries essential oils. Journal of Food Science, v.75, p.C466-472, 2010. Available from: <http:// onlinelibrary.wiley.com/doi/10.1111/j.1750-3841.2010.01711.x/ abstract>. Accessed: Jan. 20, 2014. doi: 10.1111/j.17503841.2010.01711.x

BLIGH, E.G.; DYER, W.J. A rapid method of total lipid extraction and purification. Canadian Journal of Biochemistry and Physiology, v.37, p.911-917, 1959. Available from: <http://www.nrcresearchpress.com/doi/abs/10.1139/o59-099\#. VdSPKDZRHIV>. Accessed: Mar. 25, 2015. doi: 10.1139/o59-099.

BRESSAN, M.C. et al. Effect of the factors sex and different slaughter weight in the physico-chemical characteristics of capybara meat (Hydrochaeris hydrochaeris). Ciência e Tecnologia de Alimentos, v.24, p.357-362, 2004. Available from: <http://www.scielo.br/pdf/cta/v24n3/21925.pdf>. Accessed: Mar. 19, 2015. doi: 10.1590/S0101-20612004000300009.

CISNEROS, F. et al. Influence of slaughter weight on growth and carcass characteristics, commercial cutting and curing yields, and meat quality of barrows and gilts from two genotypes. Journal of Animal Science, v.74, p.925-933, 1996. Available from: <https://www.animalsciencepublications.org/publications/jas/ abstracts/74/5/925>. Accessed: July 29, 2015. doi:/1996.745925x.

COLE, E.R. et al. Chemical composition of essential oil from ripe fruit of Schinus terebinthifolius Raddi and evaluation of its activity against wild strains of hospital origin. Brazilian Journal of Microbiology, v.45, n.3, p.821-828, 2014. Available from: <http://www.scielo.br/scielo.php?script=sci_arttext\&pid $=$ S1517-83822014000300009>. Accessed: June 15, 2015 . doi: $10.1590 / \mathrm{S} 1517-83822014000300009$.

DRANSFIELD, E. et al. Consumer choice and suggested price for pork as influenced by its appearance, taste and information concerning country of origin and organic pig production. Meat Science, v.69, p.61-70, 2005. Available from: <http://www. sciencedirect.com/science/article/pii/S0309174004001615>. Accessed: Apr. 04, 2015. doi: 10.1016/j.meatsci.2004.06.006.

FUENTES, V. et al. Impact of lipid content and composition on lipid oxidation and protein carbonylation in experimental fermented sausages. Food Chemistry, v.147, p.70-77, 2014. Available from: <http://www.sciencedirect.com/science/article/pii/ S0308814613013654>. Accessed: June 24, 2015. doi: 10.1016/j. foodchem.2013.09.100.

GOIS, F.D. et al. Effect of Brazilian red pepper (Schinus terebinthifolius Raddi) essential oil on performance, diarrhea and gut health of weanling pigs. Livestock Science, v.183, p.24-27, 2016. Available from: <http://www.sciencedirect.com/science/ article/pii/S1871141315300354>. Accessed: June 20, 2016. doi: 10.1016/j.livsci.2015.11.009.

HARTMAN, L.; LAGO, R.C. Rapid determination of fatty acid methyl esters from lipids. Laboratory Practice, v. 22, p.475-476, 1973.

HASHEMI, S.R.; DAVOODI, H. Herbal plants and their derivatives as growth and health promoters in animal nutrition.
Veterinary Research Communications, v.35, n.3, p.169-180, 2011. Available from: <http://link.springer.com/article/10.1007\% 2Fs11259-010-9458-2>. Accessed: Apr. 04, 2015. doi: 10.1007/ s11259-010-9458-2.

JERIBI, C. et al. Comparative study of bioactive compounds and antioxidant activity of Schinus terebinthifolius Raddi fruits and leaves essential oils. International Journal of Science and Research, v.3, n.12, p.453-458, 2014. Available from: <http://www.ijsr.net/archive/v3i12/U1VCMTQzODI=. pdf $>$. Accessed: July 08, 2015.

JOO, S.T. et al. Effects of dietary conjugated linoleic acid on fatty acid composition, lipid oxidation, color, and water-holding capacity of pork loin. Journal of Animal Science, v.80, p.108-112, 2002. Available from: <https://www.animalsciencepublications. org/publications/jas/abstracts/80/1/108>. Accessed: July 04, 2015. doi: /2002.801108x.

LAHUCKY, R. et al. Assessment of the antioxidant potential of selected plant extracts - in vitro and in vivo experiments on pork. Meat Science, v.85, p.779-784, 2010. Available from: <http:// www.sciencedirect.com/science/article/pii/S0309174010001282>. Accessed: Aug. 08, 2015. doi: 10.1016/j.meatsci.2010.04.004.

MADSEN, H.L. et al. The antioxidative activity of summer savory (Satureja hortensis L) and rosemary (Rosemarinus officinalis L) in dressing stored exposed to light or in darkness. Food Chemistry, v.63, p.173-180, 1998. Available from: <http://www.sciencedirect. com/science/article/pii/S0308814698000387>. Accessed: Sept. 16, 2015. doi: 10.1016/S0308-8146(98)00038-7.

MORONEY, N.C. et al. Addition of seaweed (Laminaria digitata) extracts containing laminarin and fucoidan to porcine diets: Influence on the quality and shelf-life of fresh pork. Meat Science, v.92, n.4, p.423-429, 2012. Available from: <http://www.sciencedirect.com/science/article/pii/ S0309174012001696>. Accessed: Jan. 18, 2015. doi: 10.1016/j. meatsci.2012.05.005.

RACANICCI, A.M.C. et al. Mate (Ilex paraguariensis) as dietary additive for broilers: Performance and oxidative stability of meat. European Food Research and Technology, v.232, n.4, p.655-661, 2011. Available from: <http://link.springer.com/article/10.1007/ s00217-011-1432-x>. Accessed: Jan. 02, 2015. doi: 10.1007/ s00217-011-1432-x.

RIETJENS, S.J. et al. New insights into controversies on the antioxidant potential of the olive oil antioxidant hydroxytyrosol. Journal of Agricultural and Food Chemistry, v.55, p.76097614, 2007. Available from: <http://pubs.acs.org/doi/abs/10.1021/ jf0706934>. Accessed: Jan. 02, 2016. doi: 10.1021/jf0706934.

ROSSI, R. et al. Effect of long term dietary supplementation with plant extract on carcass characteristics meat quality and oxidative stability in pork. Meat Science, v.95, p.542-548, 2013. Available from: <http://www.sciencedirect.com/science/article/pii/ S0309174013002416>. Accessed: Aug. 14, 2015. doi: 10.1016/j. meatsci.2013.05.037.

ROSTAGNO, H.S. et al. Brazilian tables for poultry and swine: composition of feedstuffs and nutritional requirements. Viçosa: Universidade Federal de Viçosa, 2011. 252p.

RYU, Y.C.; KIM, B.C. The relationship between muscle fiber characteristics, post-mortem metabolic rate, and meat quality of 
pig Longissimus dorsi muscle. Meat Science, v.71, p.351-357, 2005. Available from: <http://www.sciencedirect.com/science/ article/pii/S0309174005001476>. Accessed: Feb. 19, 2015. doi: 10.1016/j.meatsci.2005.04.015.

SILVA, M.A. et al. Brazilian red pepper oil use on the performance and intestinal morphometry of broilers. Ciência Rural, v.40, n.10, p.2151-2156, 2010. Available from: <http://www.scielo.br/pdf/cr/ v40n10/a732cr3585.pdf>. Accessed: Jan. 24, 2016. doi: 10.1590/ S0103-84782010005000160

SIMITZIS, P.E. et al. The effects of dietary oregano oil supplementation on pig meat characteristics. Meat Science, v.84, n.4, p.670-676, 2010. Available from: <http://www.sciencedirect. com/science/article/pii/S0309174009003507>. Accessed: Feb. 24, 2015. doi: 10.1016/j.meatsci.2009.11.001.
VERBEKE, W. et al. European citizen and consumer attitudes and preferences regarding beef and pork. Meat Science, v.84, n.2, p.284-292, 2010. Available from: <http://www.sciencedirect. com/science/article/pii/S0309174009001302>. Accessed: Jul. 17, 2015. doi: 10.1016/j.meatsci.2009.05.001

VISSERS, M.N. et al. Bioavailability and antioxidant effects of olive oil phenols in humans: a review. European Journal of Clinical Nutrition, v.58, p.955-965, 2004. Available from: <http://www.nature.com/ejcn/journal/v58/n6/full/1601917a. html>. Accessed: May 18, 2016. doi: 10.1038/sj.ejcn. 1601917.

YI, G. et al. Hydroperoxide formation in different lean meats. Food Chemistry, v.141, n.3, p.2656-2665, 2013. Available from: <http:// www.sciencedirect.com/science/article/pii/S0308814613006249>. Accessed: July 25, 2015. doi: 10.1016/j.foodchem.2013.05.041. 